\title{
Muhammad Fauzan
}

Fakultas Hukum Universitas Jenderal Soedirman Purwokerto

Jl. Prof. Dr. H.R. Boenyamin, No.708, Grendeng, Purwokerto Utara. E-mail:

fauzanhtndyahoo.co.id

\section{Peluang Titik Berat Otonomi Pada Daerah Provinsi dalam Sistem Ketatanegaraan Republik Indonesia}

\author{
Naskah Masuk: 21 Januari 2016 // Naskah Diterima: 6 Maret 2016 \\ DOI: 10.18196/jmh.2015.0064.1-19
}

\begin{abstract}
This research entitled: Study Focus of Provincial Autonomy In the constitutional system of the Republic of Indonesia. The result of the research can be concluded that the First, the 1945 Constitution does not give a clear regulation about the options in the unit of local authority where the policy emphasis autonomy placed. The Second, in the history of the accomplishment regional administration, the policy emphasis on the autonomy at the regional Level II/regency/City normatively used to be implemented at the time of the validity of Law Number. 5 of 1974 and Law Number. 22 of 2004. The third, in the normative perspective chances of emphasis on provincial autonomy in the future is very open, it is because at the Article 18 of the 1945 amendments to the results of an open policy (open legal policy) about regional autonomy and regional autonomy center of gravity. In these provisions, do not regulate in which the emphasis regional autonomy placed. Thus the focus wisdom of regional autonomy is highly dependent on the political will of the legislators with regard to the situation of country, such as politics, security, economy and society when the law was made and the policy of the center gravity of regional autonomy in the Provincial or the Regency/City is not contradictory with the Constitution of Republic of Indonesia Year 1945.

Keywords: Autonomy, Provincial, Indonesia
\end{abstract}

\begin{abstract}
ABSTRAK
Penelitian ini berjudul: Kajian Titik Berat Otonomi Pada Daerah Provinsi dalam Sistem Ketatanegaraan Republik Indonesia. Hasil penelitian dapat disimpulkan bahwa Pertama, UUD 1945 tidak memberikan mengatur secara jelas mengenai pilihan pada satuan pemerintan daerah mana kebijakan titik berat otonomi diletakan. Kedua, Dalam sejarah penyelenggaraan pemerintahan daerah, kebijakan titik berat otonomi pada Daerah Tingkat II/Kabupaten/Kota secara normatif pernah dilaksanakan pada saat berlakunya UU No. 5 Tahun 1974 dan UU No. 22 Tahun 2004. Ketiga, Dalam perspektif normatif peluang titik berat otonomi pada daerah provinsi pada masa yang akan datang sangat terbuka, hal tersebut dikarenakan Pasal 18 UUD 1945 hasil amandemen menganut kebijakan terbuka (open legal policy) mengenai otonomi daerah dan titik berat otonomi daerah. Dalam ketentuan-ketentuan tersebut, tidak mengatur di mana titik berat otonomi daerah diletakan. Dengan demikian kebiajakan titik berat otonomi daerah sangat tergantung pada kemauan politik pembuat undang-undang dengan memperhatikan situasi negara, seperti politik, keamanan, ekonomi dan kemasyarakatan saat UU dibuat, dan kebijakan titik berat otonomi daerah pada Daerah Provinsi maupun pada Daerah Kabupaten/Kota tidak bertentang dengan UUD RI Tahun 1945.

Kata Kunci: Otonomi, Daerah Provinsi, Indonesia
\end{abstract}




\section{PENDAHULUAN}

Berdasarkan ketentuan Pasal 1 ayat (1) UUD 1945, baik sebelum diamandemen maupun setelah diamandemen, Negara Indonesia adalah negara kesatuan yang berbentuk republik. Hal ini menunjukan bahwa para pendiri negara telah dengan sengaja memilih bentuk negara kesatuan (eenheidstaat, unitary state) bagi Indonesia, bukan bentuk negara serikat (federal satate) dan bukan pula bentuk negara konfederasi. Pertimbangan agung ini didasarkan pada kondisi empiris bangsa Indonesia yang monolitik sebagaimana tercermin dalam sikap gotong royong dan lain sebagainya (Robert Chambert, 1987: 106-107).

Pilihan otonomi yang merupakan sub-sistem dari negara kesatuan sebagai alternatif dari pilihan bentuk negara federal, bukan sekedar didasarkan pada pertimbangan teknis atau praktis, melainkan juga ditentukan oleh pertimbangan politik, pertimbangan pengalaman, pertimbangan kesejarahan, kenyataan sosial budaya dan sebagainya. Kenyataan wilayah negara dan kemajemukan dan hasrat untuk memberikan kesempatan yang seluas-luasnya kepada daerah-daerah dan berbagai kesatuan masyarakat hukum untuk berkembang secara mandiri, maka sendi penyelenggaraan pemerintahan yang sesuai adalah desentralisasi yang berinti pokok atau bertumpu pada otonomi (Bagir Manan, 2001: 22-24).

Dalam perspektif konstitusi kebijakan titik berat otonomi daerah belum pernah memperoleh kejelasan, hal tersebut sebagaimana dapat dilihat ketentuan Pasal 18 UUD 1945 sebelum diamandemen dan penjelasannya dapat disimpulkan bahwa wilayah Negara Kesatuan Republik Indonesia (NKRI) akan dibagi dalam beberapa Daerah Besar yang dalam perkembangannya dinamakan provinsi, dan Daerah Kecil yang dalam perkembangannya disebut sebagai Kabupaten/ Kota yang masing- masing memiliki otonomi, yakni kemandirian untuk menjalankan pemerintahan. Dalam perspektif Undang-undang No. 5 Tahun 1974, Daerah Besar dinamakan sebagai Provinsi/ Daerah Tingkat I, dan Daerah Kecil dinamakan Kabupaten/ Kotamadya/ Daerah Tingkat II, sementara dalam perspektif Undang-undang No. 22 Tahun 1948 dinamakan Daerah Tingkat I, Daerah Tingkat II dan Daerah Tingkat III.

Ketidak-jelasan peletakan titik berat otonomi juga diketemukan dalam UUD 1945 setelah diamandemen, sebagaimana diketahui bahwa persoalan pemerintahan daerah diamanatkan dalam Pasal 18 yang menentukan bahwa:

1) Negara Kesatuan Republik Indonesia dibagi atas daerah-daerah provinsi dan daerah provinsi itu dibagi atas kabupaten dan kota, yang tiap-tiap provinsi, kabupaten, dan kota itu mempunyai pemerintahan daerah, yang diatur dengan undangundang.

2) Pemerintahan daerah provinsi, daerah kabupaten, dan kota mengatur dan mengurus sendiri urusan pemerintahan menurut asas otonomi dan tugas pembantuan.

(3) Pemerintahan daerah provinsi, daerah kabupaten, dan kota memiliki Dewan Perwakilan Rakyat Daerah yang anggota-anggotanya dipilih melalui pemilihan umum.

(4) Gubernur, Bupati, dan Walikota masing-masing sebagai kepala pemerintah daerah provinsi, kabupaten, dan kota dipilih secara demokratis.

(5) Pemerintahan daerah menjalankan otonomi seluas-luasnya, kecuali urusan pemerintahan yang oleh undang-undang ditentukan sebagai urusan Pemerintah Pusat.

(6) Pemerintahan daerah berhak menetapkan peraturan daerah dan peraturan-peraturan lain untuk melaksanakan otonomi dan tugas pembantuan.

(7) Susunan dan tata cara penyelenggaraan pemerintahan daerah diatur dalam undang. undang.

Berdasarkan ketentuan tersebut dan 
dikaitkan dengan ketentuan Pasal 1 ayat (1), maka dapat disimpulkan prinsip otonomi daerah, yakni: pertama, otonomi daerah adalah subsistem dari Negara Kesatuan RI; kedua, susunan daerah terdiri dari provinsi dan kabupaten/ kota; ketiga, daerah otonom berhak mengatur dan mengurus rumah tangga sendiri berdasarkan otonomi dan tugas; keempat, otonomi dijalankan atas dasar otonomi seluasluasnya; kelima, negara mengakui dan menghormati satuan-satuan otonomi yang bersifat khusus atau istimewa; dan keenam, negara mengakui dan menghormati masyarakat hukum adat dan hak-hak tradisional sepanjang masing hidup dan sesuai dengan perkembangan masyarakat dan negara kesatuan (Bagir Manan, 2013: 13).

Berdasarkan uraian tersebut di atas dapat disimpulkan bahwa UUD 1945 hasil amandemen jika dibandingkan dengan pengaturan pemerintahan daerah dalam UUD 1945 sebelum diamandemen, memberikan pengaturan yang lebih komprehensif, namun demikian belum juga memberikan kejelasan pada satuan pemerintahan yang mana titik berat otonomi tersebut diletakkan dan dilaksanakan. Kesimpulan lain yang dapat dikemukakan bahwa baik dalam UUD 1945 sebelum dan sesudah diamandemen tidak memberi kejelasan atau pengaturan dalam satuan pemerintahan yang mana titik berat otonomi itu diletakkan.

Sementara jika memperhatikan beberapa ketentuan peraturan perundang-undangan yang mengatur mengenai pemerintahan daerah yang pernah berlaku di Indonesia, menentukan bahwa titik berat otonomi daerah diletakan pada daerah kabupaten/ kota, dan belum pernah terjadi dalam sejarah penyelenggaraan pemerintahan daerah yang menentukan bahwa kebijakan titik berat otonomi diletakkan daerah provinsi. Berdasarkan latar belakang tersebut, maka dapat diketengahkan perumusan masalah, yaitu bagaimanakah peluang peletakan titik berat otonomi pada Daerah Provinsi dalam sistem ketetanegaraan Republik Indonesia?

\section{PEMBAHASAN}

Dalam perspektif sejarah ketatanegaraan Republik Indonesia perdebatan mengenai pilihan bentuk negara sudah dimulai bersamaan dengan prosen penyusunan Undang Undang Dasar (UUD) yang dilakukan oleh Badan Penyelidik Usaha-usaha Persiapan Kemerdekaan Indonesia (BPUPKI), ada 2 (dua) pilihan pada saat itu, yakni pilihan sebagai negara kesatuan dan pilihan sebagai negara federal, sehingga para pendiri negara dan penyusun UUD yang diikuti oleh sebagian kelompok masyarakat "terbelah" menjadi dua, yakni kelompok unitaris, yakni kelompok yang menghendaki terbentuknya negara kesatuan, dan kelompok federalis, yakni kelompok yang menghendaki pilihan bentuk negara federal/serikat.

C.F. Stong menyatakan bahwa yang dimaksud dengan negara kesatuan adalah bentuk negara. Kekuasaan legislatif tidak terletak pada Pemerintah Daerah. Pemerintah Pusat mempunyai wewenang untuk menyerahkan sebagian kekuasaannya kepada daerah berdasarkan hak otonomi (negara kesatuan dengan sistem desentralisasi), tetapi pada tahap terakhir tetap pada Pemerintah Pusat. Jadi kedaulatannya baik ke luar maupun ke dalam sepenuhnya terletak pada Pemerintah Pusat (CF. Strong, 1966: 94).

Dalam suatu negara kesatuan pemerintah pusat biasanya memang melimpahkan banyak tugas kepada kota-kota, kabupaten-kabupaten, atau satuan pemerintah lokal atau regional. Namun, otoritas ini dilimpahkan oleh undangundang yang disusun oleh Dewan Perwakilan Rakyat Pusat (Calton Clymer Rodee, 1993: 35). Dalam pandangan Utrecht negara kesatuan ialah negara yang tidak terdiri atas beberapa daerah yang berstatus negara bagian (deelstaat), serta merdeka dan berdaulat (E. Utrecht, 1966). 
Berdasarkan uraian tersebut dapat dikatakan bahwa indikator suatu negara diklasifikasikan sebagai negara kesatuan, meliputi: (1) kedaulatan tertinggi ada pada pemerintah pusat/ nasional; (2) penyerahan suatu kekuasaan atau wewenang kepada satuan pemerintah lokal hanya dapat dilaksanakan atas kuasa undang-undang yang dibuat oleh badan legislatif nasional; dan (3) tidak ada satuan pemerintah yang lebih rendah yang mempunyai sifat staat. Dalam suatu negara kesatuan, pada hakekat semua urusan pemerintahan berada pada Pemerintah Pusat, tetapi urusan pemerintahan tersebut dapat diserahkan atau didelegasikan kepada satuan pemerintah yang lebih rendah melalui kuasa undang-undang. Dimungkinkannya penyerahan urusan pemerintahan nasional kepada satuan pemerintahan yang lebih rendah membawa konsekuensi dalam negara kesatuan diadakan pembagian wilayah negara dalam daerah besar dan kecil (Muhammad Fauzan, 2005: 87).

Perbedaan keinginan antara bentuk negara kesatuan dan bentuk negara federal/ serikat berakhir dengan dipilihnya bentuk negara kesatuan sebagai materi muatan Pasal 1 ayat (1) UUD 1945 yang disahkan pada tanggal 18 Agustus 1945, dan pilihan bentuk negara kesatuan juga ditegaskan kembali dalam Pasal 1 ayat (1) UUD 1945 hasil amandemen, bahkan di dalam Pasal 37 ayat (5) UUD 1945 hasil amandemen, Bangsa Indonesia berkomitmen untuk tidak merubah bentuk negara kesatuan. Berdasarkan uraian tersebut di atas dapat disimpulkan bahwa baik sebelum diamandemen maupun setelah diamandemen, negara Indonesia adalah negara kesatuan yang berbentuk republik.

Pilihan bentuk negara kesatuan menunjukan bahwa para pendiri negara telah dengan sengaja memilih bentuk negara kesatuan (eenheidstaat, unitary state) bagi Indonesia, bukan bentuk negara serikat (federal satate) dan bukan pula bentuk negara konfederasi. Pertimbangan agung ini didasarkan pada kondisi empiris bangsa Indonesia yang monolitik sebagaimana tercermin dalam sikap gotong royong dan lain sebagainya. (Robert Chambert, 1987: 106-107). Eksistensi Pemerintah Daerah Provinsi dalam sistem ketatanegaraan RI diamanatkan langsung dalam UUD 1945 hasil amandemen, hal tersebut dapat disimpulkan dari ketentuan Pasal 18 yang menentukan bahwa: Pertama, Negara Kesatuan Republik Indonesia dibagi atas daerahdaerah provinsi dan daerah provinsi itu dibagi atas kabupaten dan kota, yang tiap-tiap provinsi, kabupaten, dan kota itu mempunyai pemerintahan daerah, yang diatur dengan undang-undang. Kedua, Pemerintahan daerah provinsi, daerah kabupaten, dan kota mengatur dan mengurus sendiri urusan pemerintahan menurut asas otonomi dan tugas pembantuan. Ketiga, Pemerintahan daerah provinsi, daerah kabupaten, dan kota memiliki Dewan Perwakilan Rakyat Daerah yang anggotaanggotanya dipilih melalui pemilihan umum. Dan Keempat, Gubernur, Bupati, dan Walikota masing-masing sebagai kepala pemerintah daerah provinsi, kabupaten, dan kota dipilih secara demokratis.

Ketentuan mengenai pembagian wilayah Indonesia menjadi daerah provinsi, dan masingmasing provinsi dibagi kedalam kabupaten/ kota merupakan ketentuan yang memperjelas mengenai bentuk satuan pemerintahan yang diinginkan oleh konstitusi. Hal tersebut berbeda ketika berlakunya UUD 1945 sebelum diamandemen karena dalam Pasal 18 UUD hanya ditentukan bahwa: Pembagian Daerah atas Daerah besar dan kecil, dengan bentuk susunan pemerintahannya ditetapkan dengan undang-undang dengan memandang dan mengingat dasar permusyawaratan dalam sidang Pemerintahan Negara dan hak-hak asal-usul dalam daerah yang bersifat Istimewa.

Memperhatikan ketentuan tersebut, maka 
dalam praktek penyelenggaraan pemerintahan di Indonesia, "daerah besar dan lecil" serta bentuk dan susunannya ditentukan melalui kesepakatan para bentuk undang-undang pelaksanaannya. Undang-undang No. 5 Tahun 1974 tentang Pokok Pokok Pemerintahan di Daerah "menerjemahkan" "daerah besar dan kecil" dalam bentuk Daerah Tingkat I dan Daerah Tingkat II. Hal tersebut sebagaimana diamanatkan di dalam Pasal 3 ayat (1) yang menentukan bahwa: Dalam rangka pelaksanaan azas desentralisasi dibentuk dan disusun Daerah Tingkat I dan Daerah Tingkat II. Sementara dalam Undang-undang No. 22 Tahun 1999 “daerah besar dan kecil” bentuk dan susunannya diatur dalam Pasal $2 \mathrm{~s} / \mathrm{d} 5$ yang secara garis besar menentukan bahwa:

a. Wilayah Negara Kesatuan Republik Indonesia dibagi dalam Daerah Propinsi, Daerah Kabupaten, dan Daerah Kota yang bersifat otonom.

b. Daerah Propinsi berkedudukan juga sebagai Wilayah Administrasi.

c. Wilayah Daerah Propinsi, terdiri atas wilayah darat dan wilayah laut sejauh dua belas mil laut yang diukur dari garis pantai ke arah laut lepas dan atau ke arah perairan kepulauan.

d. Dalam rangka pelaksanaan asas

Desentralisasi dibentuk dan disusun Daerah Propinsi, Daerah Kabupaten, dan Daerah Kota yang berwenang mengatur dan mengurus kepentingan Dalam rangka pelaksanaan asas Desentralisasi dibentuk dan disusun Daerah Propinsi, Daerah Kabupaten, dan Daerah Kota yang berwenang mengatur dan mengurus kepentingan masyarakat.

e. Masing-masing berdiri sendiri dan tidak mempunyai hubungan hierarki satu sama lain.

Berdasarkan uraian tersebut di atas, maka dapat disimpulkan bahwa pengaturan mengenai eksistensi Daerah Provisni termasuk di dalamnya Daerah Kabupaten dan Kota dalam
UUD 1945 hasil amandemen jauh lebih komprehensif dan jelas. Kesimpulan lain yang dapat diambil dari ketentuan tersebut bahwa Daerah Provinsi mempunyai kesudukan disampaing sebagai daerah otonom, yakni daerah yang mempunyai kewenangan untuk mengatur dan mengurus urusan pemerintahan sendiri berdasarkan atas prakarsa sendiri, juga mempunyai kedudukan sebagai Wilayah Administratif.

Terdapat perbedaan implementasi dari "daerah besar dan kecil" antara Undang-undang No. 5 Tahun 1974 dengan Undang-undang No. 22 Tahun 1999. Berdasarkan Undang-undang No. 5 Tahun 1974 "daerah besar" diterjemahkan sebagai Daerah Tingkat I, sedangkan berdasarkan Undang-undang No. 22 Tahun 1999 Propinsi Daerah Tingkat I menurut Undang-undang Nomor 5 Tahun 1974, dalam Undang-undang No. 22 Tahun 1999 dijadikan Daerah Propinsi dengan kedudukan sebagai Daerah Otonom dan sekaligus Wilayah Administrasi, yang melaksanakan kewenangan Pemerintah Pusat yang didelegasikan kepada Gubernur. Daerah Propinsi bukan merupakan Pemerintah atasan dari Daerah Kabupaten dan Daerah Kota. Dengan demikian, Daerah Otonom Propinsi dan Daerah Kabupaten dan Daerah Kota tidak mempunyai hubungan hierarki.

Berdasarkan Penjelasan Umum huruf (g) Undang-undang No. 22 Tahun 1999, pemberian kedudukan provinsi sebagai wilayah administratif dengan pertimbangan:

1) Untuk memelihara hubungan yang serasi antara Pusat dan Daerah dala m kerangka Negara Kesatuan Republik Indonesia;

2) Untuk menyelenggarakan Otonomi Daerah yang bersifat lintas Daerah Kabupaten dan Daerah Kota serta melaksanakan kewenangan Otonomi Daerah yang belum dapat dilaksanakan oleh Daerah Kabupaten dan Daerah Kota; dan 
3) Untuk melaksanakan tugas-tugas pemerintahan tertentu yang dilimpahkan dalam rangka pelaksanaan asas dekonsentrasi.

Berlakunya Undang-undang No. 22 Tahun 1999 dalam tataran praktis telah mengakibatkan disharmonisasi antara Daerah Provinsi yang sekaligus berkedudukasn sebagai wilayah administratif dengan daerah kabupaten/ kota yang hanya berkedudukan sebagai daerah otonom. Salah satu sebab disharmonisasi hubungan antara satuan pemerintahan tersebut adalah ketentuan Pasal 4 ayat (2) yang menentukan bahwa masing-masing daerah (baca = provinsi/ kabupaten/kota sebagai daerah otonom) tidak mempunyai hubungan hirarkhis satu sama lain.

Keadaan tersebut telah banyak mengakibatkan penyelenggaraan pemerintahan daerah tidak berjalan sebagaimana mestinya, terlebih sebagai daerah otonom provinsi mempunyai kewenangan untuk menyelenggarakan urusan-urusan pemerintahan yang lintas daerah kabuaten/kota, pelaksanaan urusan yang bersifat lintas kabupaten/ kota sering tidak bisa berjalan optimal karena perbedaan kebijakan antara daerah provinsi dengan daerah kabupaen/kota.

Memperhatikan hal tersebut, maka Undangundang U No. 22 Tahun 1999 diganti dengan diundangkannya Undang-undang No. 32 Tahun 2004. Berlakunya Undang-undang No. 32 Tahun 2004 adalah dalam rangka menyesuaikan dengan Pasal 18 UUD 1945 hasil amandemen, karena UUD 1945 sudah tidak menggunakan lagi istilah "daerah besar dan kecil”. UUD 1945 hasil amandemen mengatur mengenai pembagian wilayah Indonesia sebagamana diamanatkan dalam Pasal 18 ayat (1) yang menegaskan bahwa: Negara Kesatuan Republik Indonesia dibagi atas daerah-daerah provinsi dan daerah provinsi itu dibagi atas kabupaten dan kota, yang tiap-tiap provinsi, kabupaten, dan kota itu mempunyai pemerintahan daerah, yang diatur dengan undang-undang.

Berdasarkan undang-undang yang mengatur mengenai pemerintahan daerah pasca UUD 1945, baik Undang-undang No. 32 Tahun 2004 maupun Undang-undang No. 23 Tahun 2014, secara tegas "menerjemahkan" "daerah besar" adalah Daerah Provinsi dan "daerah kecil" adalah Daerah Kabupaten/Kota. Hal tersebut dapat dilihat dari ketentuan Pasal 2 ayat (1) Undang-undang No. 32 Tahun 2004 yang menentukan bahwa: Negara Kesatuan Republik Indonesia dibagi atas daerah-daerah provinsi dan daerah provinsi itu dibagi atas kabupaten dan kota yang masing-masing mempunyai pemerintahan daerah. Demikian juga dengan ketentuan Pasal 2 ayat (1) Undang-undang No. 23 Tahun 2014 yang menegaskan bahwa: Negara Kesatuan Republik Indonesia dibagi atas Daerah provinsi dan Daerah provinsi itu dibagi atas Daerah kabupaten dan kota.

Berdasarkan uraian tersebut di atas, maka terkait peluang titik berat otonomi pada Daerah Provinsi sudah barang tentu yang harus dilihat adalah peraturan perundang-undangan yang mengatur masalah pemerintahan daerah. Sebagaimana telah dikemukakan di atas, bahwa UUD 1945 hasil amandemen tidak mengatur secara jelas pada satuan daerah mana kebijakan titik berat otonomi itu dilaksanakan.

Ketika UUD 1945 tidak mengatur secara jelas tentang kebijakan titik berat otonomi pada satuan daerah tertentu, maka jika dilihat dalam praktek penyelenggaraan pemerintahan yang pernah dilaksanakan di Indonesia sebagaimana telah dikemukakn di atas, bahwa ada pada saat tertntu secara tegas berdasarkan undang-undang dan peraturan pemerintah, kebijakan otonomi diletakan pada daerah kabupaten/Kota/Daerah Tingkat II, hal tersebut menunjukan bahwa peletakan kebijakan otonomi pada satuan daerah tersebut tidak bertentangan dengan UUD 1945. Demikian juga sebaliknya, ketiadaan pengaturan yang melarang peletakan 
titik berat otonomi pada Daerah Provinsi di dalam UUD 1945 hasil amandemen juga dapat disimpulkan bahwa hal tersebut sangat mungkin dilaksanakan.

Terkait dengan hal tersebut, Teras Narang menyatakan bahwa UUD RI 1945 hanya mengatur tentang otonomi daerah dan tidak mengatur mengenai "titik berat otonomi” dan tidak pula menentukan pada daerah mana otonomi daerah diletakan. "itik berat otonomi daerah tidak diatur secara detail dalam UUD RI 1945. Konstitusi kita menganut kebijakan terbuka (open legal policy) mengenai otonomi daerah dan titik berat otonomi daerah.

Pengaturan otonomi daerah dan hubungan kewenangan antara pemerintah daerah diatur dalam Pasal 18 ayat (2), (5) dan Pasal 18A ayat (1) UUD 1945. Dalam ketentuan-ketentuan tersebut, tidak mengatur di mana titik berat otonomi daerah diletakan. Titik berat otonomi daerah diatur dalam undang-undang dengan memperhatikan situasi negara, seperti politik, keamanan, ekonomi dan kemasyarakatan saat undang-undang dibuat, dan kebijakan titik berat otonomi daerah pada kabupaten dan kota memang tidak bertentang dengan UUD 1945. Namun, sejak pemberlakuan otonomi daerah di kabupaten dan kota sejak adanya Undangundang No. 5 Tahun 1974, Peraturan Pemerintah No. 45 Tahun 1992, Undangundang No.22 Tahun 1999, dan Undangundang No. 32 Tahun 2004 tidak membawa hasil yang diharapkan dalam mewujudkan tujaan negara dan tujuan otonomi itu sendiri. (http://sp.beritasatu.com/home/peletakanotonomi-daerah-pada-provinsi-tidak-langgarkonstitusi/88548, diunduh pada tanggal 10 Januari 2016).

Memperhatikan hal tersebut maka dapat dikatakan bahwa peluang pelaksanaan kebijakan otonomi dengan titik berat pada Daerah Provinsi sangat tergantung pada situasi negara, seperti politik, keamanan, ekonomi dan kemasyarakatan saat undang-undang dibuat, artinya sangat tergantung pada kebijakan yang akan diambil oleh pembuat undang-undang, hal tersebut karena mengenai kebijakan titik berat otonomi akan diletakan pada satuan daerah mana merupakan open legal policy.

Dalam banyak hal, kebijakan peletakan titik berat otonomi pada Kabupaten/Kota dengan prinsip otonomi yang seluas-luasnya telah berakibat timbulnya "daerahisme" dari Daerah Kabupaten/Kota yang bersangkutan, bahkan kenderungan untuk bersikap "mbalelo" dari Daerah Kabupaten/Kota kepada Daerah Provinsi sering dijumpai. Terlebih ketika Pasal 4 ayat (2) Undang-undang No. 22 Tahun 1999 menegaskan bahwa masing-masing daerah otonom (provinsi dan kabupaten/kota) tidak mempunyai hubungan khirarkis satu sama lain.

Memperhatikan uraian tersebut di atas dapat disimpulkan bahwa, pertama, UUD 1945, baik sebelum diamandemen, maupun setelah diamandemen tidak memberikan kejelasan pada satuan pemerintahan daerah yang mana, titik berat otonomi itu diletakan, kemudian, kedua, berdasarkan peraturan perundang-undangan di bidang pemerintahan daerah, pelaksanaan titik berat otonomi hanya terjadi pada daerah kabupaten/kota, namun demikian dalam Undang-undang No. 32 Tahun 2004 jo Undangundang No. 12 Tahun 2008, dan Undangundang No. 23 Tahun 2014 tidak ditentukan secara eksplisit bahwa kebijakan titik berat otonomi diletakan pada daerah kabupaten/ kota.

Fakta yang terjadi ketika titik berat otonomi dititik beratkan kepada kabupaten/ kota setelah reformasi bergulir mulai dari tahun 1998 sampai sekarang efektifitas penyelenggaraan dan stabilitas pemerintahan di daerah tidak berjalan sebagaimana yang diharapkan karena bagaimana jalur hubungan antara pemerintahan daerah provinsi dan pemerintahan daerah kabupaten/ kota tersebut tidak berjalan dengan baik. Di 
daerah sekarang gampang terjadi

"bersinggungan" antara pemerintahan daerah provinsi dan daerah kabupaten/ kota sehingga jalur koordinasi antara pemerintahan daerah itu tidak berjalan efektif. Di satu sisi daerah kabupaten/kota berdalih bahwa hanya merekalah yang mempunyai otonomi sedangkan daerah provinsi tidak memiliki daerah karena provinsi hanyalah perpanjangan tangan pemerintah pusat di daerah sesuai dengan asas dekonsentrasi yang diberikan kepada wilayah provinsi sesuai UU No.32 Tahun 2004 (Resa Indrawan Samir http:// resaindrawansamir.wordpress.com/2011/05/ 26/pengembalian-titik-berat-otonomi-ditingkatprovinsi/, diunduh pada tanggal 10 Januari 2016).

Di sisi lain sering dijumpai persoalan lempar tanggung jawab atas masalah yang dihadapai masyarakat, sebagai contoh ketika masyarakat menghendaki adanya perbaikan dengan segera atas fasilitas atau infrastruktur jalan yang rusak, maka akan dilihat terlebih dahulu status jalan tersebut, apakah jalan provinsi atau jalan kabupaten/kota, jika yang rusak jalan provinsi, maka hal itu menjadi tanggung jawab Pemerintah Provinsi, sekalipun jalan tersebut nyata-nyata ada di depan "mata" Pemerintah Kabupaten/Kota. Kondisi tersebut tentunya tidak menguntungkan masyarakat, karena masyarakat akhirnya tidak memperoleh pelayanan dengan baik, masyarakat tidak akan memperdulikan apakan jalan tersebut kewenangan Pemerintah Provinsi atau Pemerintah Kabupaten/ Kota, yang penting masyarakat kebutuhan akan kenyamanan dan keselamatan dalam menggunakan jalan umum terpenuhi.

Fakta lain ketika peletakan titik berat otonomi di daerah kabupaten/ kota, banyak Bupati/ walikota yang tidak dilantik oleh Gubernur karena sebuah alasan bahwa daerah
Provinsi hanyalah daerah administratif (dekonsentrasi) sehingga banyak Bupati/ walikota banyak "membandel" dan dilantik oleh Menteri luar Negeri di Departemen dalam Negeri karena tidak mau dilantik oleh Gubernur sedangkan dalam Undang-undang No.32 Tahun 2004 Jo. Undang-undang No.12 Tahun 2008 Pasal 111 bahwa "Bupati dan Wakil Bupati atau Walikota dan Wakil Walikota dilantik oleh Gubernur atas nama Presiden".

Hal lain yang perlu mendapatkan perhatian adalah bahwa pada era pelaksanaan otonomi yang seluas-luasnya dengan titik berat pada Daerah Kabupaten/ Kota, hasrat untuk membentuk daerah otonomi baru seakan tidak bisa dibendung, tercatat sampai dengan bulan Juli 2013 jumlah provinsi di Indonesia terus bertambah hingga mencapai 34 provinsi, kabupaten 410, dan kota 98. Atau jumlah daerah otonom baru baik provinsi/kabupaten/ kota pembentukan antara Tahun 1999 sampai dengan Tahun 2013 seluruhnya berjumlah 217 daerah otonomi baru yang meliputi 8 (delapan) Daerah Provinsi,dan 175 (seratus tujuh puluh lima) Kabupaten dan 34 (tigapuluh empat) Daerah Kota. Bahkan sampai dengan bulan Desember 2013 terdapar terdapat 65 dokumen usulan daerah otonomi baru yang sudah diajukan oleh pemerintah kepada DPR.

Banyaknya daerah otonomi baru sebenarnya tidak serta merta daerah mampu untuk melaksanakan otonomi yang diberikan kepada daerah yang bersangkutan, Jangankan untuk daerah otonomi baru, atau daerah otonom hasil pemekaran, daerah otonom yang sudah lamapun belum tentu dapat melaksanakan otonominya secara idial, karena menurut pemahaman saya, otonomi yang idial akan dapat diwujudkan manakala daerah otonom tersebut, di samping memiliki kemampuan untuk membuat perencanaan dan bagaimana pelaksanaan dari perencanaan tersebut, tetapi juga mempunyai kemampuan untuk membiayai 
setiap pelaksanaan kegiatan penyelenggaraan pemerintahan.

Di atas telah dikemukakan, bahwa kebijakan titik berat otonomi pada daerah kabupaten/ kota, karena kedua satuan pemerintahan tersebut memiliki kedekatan dengan masyarakat/ rakyat, sehingga diharapkan mampu untuk mengetahui dan memahami keinginan dan kebutuhan masyarakat serta dalam rangka meningkatkan pelayanan kepada masyarakat dan pelaksanaan pembangunan, tetapi juga dalam rangka memperpendek birokrasi pemerintahan. Namun demikian dalam kenyataannya, tidak semua daerah kabupaten/kota mampu untuk melaksanakan otonomi dengan baik, karena yang perlu diperhatikan, bahwa dalam pelaksanaan kebijakan titik berat otonomi terdapat beberapa persyaratan yang harus dipenuhi agar kebijakan tersebut dapat dilaksanakan sesuai dengan tujuan dan arah yang telah digariskan.

Beberapa persyaratan yang harus dipenuhi antara lain: Pertama, ketersediaan sumber daya manusia yang memiliki kemampuan dan pengetahuan yang diperlukan sesuai dengan bidang keahliannya; Kedua, ketersediaan kemampuan keuangan daerah untuk membiayai penyelenggaraan semua urusan pemerintahan yang diserahkan kepada daerah, dan Ketiga, ketersediaan sarana dan prasarana yang memadahi untuk mempermudah penyelenggaraan pemerintahan; Keempat, adanya pemahaman yang sama diantara para penyelenggara pemerintahan di daerah, bahwa kebijakan titik berat otonomi semata-mata dalam rangka memperkuat eksistensi Negara Kesatuan Republik Indonesia.

Ketersediaan sumber daya manusia yang berkualitas, yang memiliki kemampuan dan pengetahuan yang baik tentang penyelenggaraan pemerintahan akan mempermudah daerah otonom untuk tumbuh dan berkembang sesuai dengan garis politik otonomi daerah. Hal ini disebabkan, dengan kebijakan otonomi tersebut, daerah memiliki keleluasaan untuk mengatur dan mengurus daerahnya, oleh karena itu daerah otonom akan maju dan berkembang atau bahkan sebaliknya (baca tertinggal dari daerah lainnya) salah satu faktornya sangat dipengaruhi oleh daya kreativitas dan kemampuan berinovasi aparatur penyelenggara pemerintahan.

Persyaratan ketersediaan kemampuan keuangan daerah juga menjadi salah satu faktor yang harus dipertimbangkan, karena betapapun daerah otonom tersebut didukung oleh SDM yang memiliki kreativitas tinggi dalam memajukan daerahnya, tetapi tidak didukung dengan ketersediaan dana, maka perencanaan dan kreatifitas daerah hanya akan menjadi "program" yang indah dalam tatatan konsep dan cita-cita, tetapi tidak akan pernah dapat diimplementasikan dan diwujudkan dalam kehidupan masyarakat. Memperhatikan hal tersebut, maka kebijakan titik berat otonomi daerah pada daerah Kabupaten/Kota yang sekarang masih dijalankan oleh pemerintah Indonesia, menunjukan bahwa tingkat ketergantungan kabupaten/kota, khususnya berkaitan dengan ketersediaan dana, masih sangat besar baik melalui mekanisme Dana Alokasi Umum (DAU).

Berdasarkan Peraturan Presiden No. 2 Tahun 2014 tentang Dana Alokasi Umum Daerah Provinsi dan Kabupaten/Kota, DAU ditetapkan $26 \%$ (dua puluh enam persen) dari Pendapatan Dalam Negeri Netto yang ditetapkan dalam Anggaran Pendapatan dan Belanja Negara (APBN), dan dari alokasi tersebut, $10 \%$ (sepuluh persen) untuk Daerah Provinsi dan 90 $\%$ (sembilan puluh persen) untuk Daerah Kabupaten/Kota dari total DAU sebesar Rp. 341.219.325.651.000,- (Tiga ratus empat puluh satu triliun dua ratus sembilan belas milyar tiga ratus dua puluh lima juta enam ratus lima puluh satu ribu rupiah). Di samping ketersediaan dan 
kemampuan pendanaan, aspek lain yang perlu diperhatikan agar kebijakan titik berat otonomi daerah pada daerah Kabupaten/Kota dapat berhasil, adalah ketersediaan sarana dan prasararana, ketersediaan sarana dan prasarana ini juga berkaitan dengan kemampuan keuangan daerah untuk menyediakan sarana dan prasarana tersebut.

Berkaitan dengan hal tersebut Triono Budi Sasongko yang sekarang berkedudukan sebagai pejabat Gubernur Provinsi Kalimantar Timur dalam sebuah wawancara berpendapat, bahwa peletakan titik berat otonomi yang tepat adalah pada Daerah Kabupaten/Kota, karena satuan pemerintahan daerah Kabupaten/ Kota merupakan Daerah yang sangat bersentuhan dengan masyarakat, sehingga tingkat pengetahuan atas persoalan-persoalan dan aspirasi masyarakat menjadi modal penting untuk memajukan dan membangun daerah yang bersangkutan, karena sebagaimana diketahui bahwa tujuan pemberian otonomi salah satunya adalah meningkatkan kesejahteraan rakyat. (Wawancara dengan Triono Budi Sasangko pada tanggal 30 September 2015 di Kementerian Dalam Negeri Republik Indonesia).

Sementara itu Wakil Gubernur Jawa Tengah berpendapat bahwa kebijakan peletakan otonomi pada Daerah Provinsi sangat dimungkinkan, terlebih jika dilihat dari kemampuan Daerahnya, baik kemampuan di bidang sumber daya manusia maupun kemampuan di bidang keuangan daerah, kebijakan otonomi akan sangat dipengaruhi oleh ketersediaan dana dan anggaran yang tersedia, Daerah Provinsi, khususnya Jawa Tengah jika dilihat dari ketersediaan dana dalam Anggaran Pendapatan Dan Belanja Daerah, sangat memungkinkan jika kebijakan otonomi diletakan pada Daerah Provinsi. Pada bagian lain, Heru Sudjatmoko juga sependapat dengan peneliti, bahwa peletakan titik berat otonomi pada satuan daerah mana, apakah ada Daerah Provinsi mauun Daerah Kabuapaten/Kota dalam kerangka Negara Kesatuan RI tidak serta merta harus disamakan, bagi daerah-daerah yang mempunyai kemampuan daerah tinggi, maka sudah sepantasnya kebijakab titik berat otonomi diletakanpada daerah yang bersangkutan, atau dengan perkataan lain, jika suatu Daerah Provinsi ternyata tidak memiliki kemampuan, maka tidak seharusnya titik berat otonomi diletakan pada daerah yang bersangkutan.(Wawancara dengan Wakil Gubernur Provinsi Jawa Tengah pada tanggal 5 Oktober 2014 di Semarang).

Memperhatikan hal tersebut, maka dalam sistem ketatanegaraan RI pada masa yang akan datang sangat terbuka adanya adanya "kombinasi" pelaksanaan titik berat otonomi, yakni pertama, bagi daerah Kabupaten/Kota yang memiliki kemampuan baik kemampuan di bidang sumber daya manusia maupun sumber dana maka kebijakan otooni diletakan pada Daerah Kabupaten/Kota, Kedua, jika ternyata Daerah Kabupaten/Kota tidak memiliki kemampuan tersebut, maka kebijakan titik berat otonomi yang lebih tepat diletakan pada Daerah Provinsi.

Hal lain yang harus diperhatikan dalam pelaksanaan kebijakan titik berat otonomi adalah adanya pemahaman yang sama, bahwa kebijakan otonomi akan selalu berhubungan dengan pilihan bentuk negara kesatuan, oleh karena itu pikiran dan banyangan bahwa dengan kebijakan otonomi yang seluas-luasnya dengan menitik beratkan pada tingkatan daerah tertentu akan mendorong hasrat menjadi daerah yang "merdeka" harus dibuang jauh-jauh dari masyarakat daerah, tetapi harus disadari dan dipahami bahwa kebijakan titik berat otonomi tersebut dilaksanakan untuk mendorong akselerasi daerah otonom yang bersangkutan agar mampu meningkatkan kesejahteraan masyarakat, meningkatkan 
pelayanan masyarakat, meningkatkan kemandirian serta pembangunan daerah.

Dengan demikian pemahaman mengenai pemberian otonomi seluas-luasnya adalah tetap dalam kerangka NKRI, maka walaupun menggunakan terminologi seluas-luasnya tetap dalam pembatasan-pembatasan yang dilakukan oleh Pemerintah Pusat dalam rangka mencegah terjadinya disintegrasi NKRI. Dari sudut pandang hukum, kebijakan otonomi seluasluasnya tetap masih dengan pembatasanpembatasan yang diwujudkan dalam peraturan perundang-undangan yang memiliki karakteristik sebagai berikut: (http:// edikuncoro.wordpress.com/2010/10/27/ otonomi-daerah-sebelum-amandemen-uud1945/, diunduh 10 Januari 2016)

1. Memberikan wenangan kepada Pemerintah Pusat untuk setiap saat menentukan urusanurusan Pemerintahan yang menjadi wewenangnya.

2. Memberikan wewenang kepada Pusat untuk menarik kembali atau mengalihkan urusan rumah tangga daerah menjadi urusan Pusat.

3. Memberikan wewenang untuk menolak hasrat suatu Pemerintah Daerah Otonom untuk mengatur dan mengurus urusan Pemerintahan tertentu

4. Memberikan wewenang kepada pusat untuk melakukan pengawasan terhadap jalannya pemerintahan daerah baik preventif, represif, maupun dalam bentuk-bentuk pengawasan lainnya.

Memperhatikan uraian tersebut di atas, maka dapat disimpulkan bahwa kebijakan pemberian otonomi yang seluas-luasnya dengan titik berat pada daerah otonom tertentu tidak akan berakibat hilangnya kewenangan Pemerintah Pusat untuk tetap melakukan pembinaan dan evaluasi terhadap pelaksanaan kebijakan tersebut, bahkan dalam tataran tertentu Pemerintah Pusat atas kuasa peraturan perundang-undangan dapat menarik kembali urusan-urusan pemerintahan yang telah diserahkan kepada satuan daerah otonom. Sepanjang sejarah ketatanegaraan RI titik berat otonomi pada Daerah Provinsi memang belum pernah dilaksanakan, namun demikian hal tersebut bukan berarti tidak dimungkinkan, sekalipun masih dalam tataran konsep, ide dan gagasan. Menentukan pilihan kebijakan titik berat otonomi dengan locus-nya ada pada satuan Pemerintahan Daerah Provinsi secara konstitusional masih terbuka, karena dalam UUD 1945 pasca amandemen, ternyata tidak ada penjelasan/ketentuan yang secara eksplisit mengamanatkan diletakan pada satuan pemerintahan daerah mana titik berat otonomi dilaksanakan.

Ketentuan Pasal 18 ayat (1) UUD 1945 hasil amandemen sebagaimana telah dikemukakan di atas hanya mengamanatkan bahwa: "Negara Kesatuan Republik Indonesia dibagi atas daerahdaerah provinsi dan daerah provinsi dibagi atas kabupaten dan kota, yang tiap-tiap provinsi, kabupaten, dan kota itu mempunyai pemerintahan daerah, yang diatur dalam undang-undang". Ketentuan tersebut diperjelas dalam Pasal 18 ayat (2) yang menentukan bahwa: Pemerintahan daerah provinsi, daerah kabupaten, dan kota mengatur dan mengurus sendiri urusan pemerintahan menurut asas otonomi dan tugas pembantuan.

Berdasarkan ketentuan Pasal 18 ayat (1) dan (2) tersebut dapat disimpulkan bahwa sistem yang diatur dalam UUD 1945 hasil amandemen tidak memberikan perbedaan antara Daerah Provinsi dengan Daerah Kabupaten/Kota, karena baik Daerah Provinsi mapun Daerah Kabupaten/Kota sama-sama memiliki pemerintahan daerah serta kewenangan untuk mengatur dan mengurus urusan pemerintahan menurut asas otonomi dan tugas pembantuan. Dengan demikian, maka baik Daerah Provinsi maupun Daerah Kabupaten/Kota mempunyai kesempatan yang sama untuk melaksanakan kebijakan sebagai locus titik berat otonomi. 
Memperhatikan hal tersebut maka dapat dikatakan bahwa pemikiran untuk mengeluarkan kebijakan peletakan titik berat otonomi pada Daerah Provinsi secara konstitusional tidak bertentangan dengan UUD 1945, hal tersebut sebagaimana telah dikemukakan di atas, UUD 1945 tidak secara tegas mengamanatkan bahwa titik berat otonomi harus dititikberatkan diwilayah provinsi atau kabupaten/kota tetapi antara provinsi, kabupaten/kota mempunyai peluang yang sama untuk mendapatkan titikberat otonomi di daerahnya.

Kebijakan peletakan titik berat otonomi pada Daerah Kabupaten/Kota secara normatif lebih disebabkan derivasi undang-undang terhadap UUD 1945 yang dilakukan oleh Presiden dan DPR dalam merumuskan undang-undang yang mengatur pemerintahan daerah. Dengan demikian, kebijakan untuk meletakan titik berat otonomi pada daerah provinsi bukan sebuah kebijakan yang bertentangan dengan UUD 1945 dan bukan merupakan sesuatu yang sulit dilakukan karena pengaturannya hanya berada dalam tatanan undang-undang bukan dalam tatanan UUD 1945.

Berdasarkan Undang-undang No. 32 Tahun 2004, Daerah Provinsi memang diberi wewenang untuk mengatur dan mengurus urusan pemerintahan, yang menggariskan bahwa NKRI dibagi atas daerah-daerah provinsi dan daerah provinsi itu dibagi atas kabupaten dan kota yang masing-masing mempunyai pemerintahan daerah, mengatur dan mengurus sendiri urusan pemerintahan menurut asas otonomi dan tugas pembantuan serta menjalankan otonomi seluas-luasnya, kecuali urusan pemerintahan yang menjadi urusan Pemerintah, dengan tujuan meningkatkan kesejahteraan masyarakat, pelayanan umum, dan daya saing daerah. Sementara berdasarkan Pasal 2 ayat (1) Undang-undang No. 23 Tahun 2014 dinyatakan bahwa Negara Kesatuan
Republik Indonesia dibagi atas Daerah provinsi dan Daerah provinsi itu dibagi atas Daerah kabupaten dan kota. Bahkan dalam ayat (2) dinyatakan bahwa Daerah kabupaten/kota dibagi atas Kecamatan dan Kecamatan dibagi atas kelurahan dan/atau Desa.

Di samping hal tersebut, Daerah Provinsi yang sebenarnya merupakan daerah otonom dan dipimpin oleh gubernur yang memiliki 2 (dua) kedudukan, yakni sebagai Kepala Daerah Otonom sekaligus sebagai Wakil Pemerintah Pusat di Daerah. Hal tersebut dapat disimpulkan dari batasan mengenai nomenklatur "dekonsentrasi" sebagaimana diatur dalam Pasal 1 ayat (8) UU No. 32 Tahun 2004 yang menentukan bahwa: Dekonsentrasi adalah pelimpahan wewenang pemerintahan oleh pemerintah kepada Gubernur sebagai wakil pemerintah dan/atau kepada instansi vertikal diwilayah tertentu.

Berbeda dengan ketentuan tersebut, Undangundang No. 23 Tahun 2014 bahkan memberikan dua status baik sebagai daerah otonom maupun wilayah administrasi kepada provinsi maupun kabupaten/kota. Hal tersebuy sebagaimana diamanatkan dalam Pasal 4 yang menentukan bahwa:

1) Daerah provinsi selain berstatus sebagai Daerah juga merupakan Wilayah Administratif yang menjadi wilayah kerja bagi gubernur sebagai wakil Pemerintah Pusat dan wilayah kerja bagi gubernur dalam menyelenggarakan urusan pemerintahan umum di wilayah Daerah provinsi.

2) Daerah kabupaten/kota selain berstatus sebagai Daerah juga merupakan Wilayah Administratif yang menjadi wilayah kerja bagi bupati/wali kota dalam menyelenggarakan urusan pemerintahan umum di wilayah Daerah kabupaten/kota. Sebagai Wakil Pemerintah Pusat, gubernur memiliki tugas yang tidak ringan karena harus menjamin terlaksananya visi dan misi serta program Pemerintah Pusat, terutama tugas-tugas pemerintahan umum seperti stabilitas dan 
integrasi nasional, koordinasi pemerintahan dan pembangunan, serta pengawasan penyelenggaraan pemerintahan kabupaten/kota. Di samping itu, berdasarkan ketentuan Pasal 38 ayat (1) Undang-undang No. 32 Tahun 2004, Gubernur sebagai Wakil Pemerintah Pusat memiliki tugas dan wewenang sebagai berikut Pertama Pembinaan dan pengawasan penyelenggaraan pemerintahan daerah kabupaten/kota. Kedua, Koordinasi penyelenggaraan urusan pemerintah di daerah provinsi dan kabupaten/kota.Dan, Ketiga, Koordinasi pembinaan dan pengawasan penyelenggaraan tugas pembantuan di daerah provinsi dan kabupaten/kota. Sedangkan, gubernur sebagai Kepala Daerah tugas gubernur adalah menyelenggarakan otonomi seluasluasnya, utamanya urusan lintas kabupaten/ kota, kecuali urusan pemerintahan yang ditentukan undang-undang sebagai urusan Pemerintah Pusat.

Sementara berdasarkan Undang-undang No. 23 Tahun 2014, Gubernur sebagai Wakil Pemerintah Pusat, termasuk di dalamnya Bupati/Walikota adalah dalam rangka menyelenggarakan urusan pemerintahan umum, yakni urusan pemerintahan yang berkaitan dengan beberapa hal sebagai berikut:

a. Pembinaan wawasan kebangsaan dan ketahanan nasional dalam rangka memantapkan pengamalan Pancasila, pelaksanaan Undang-Undang Dasar Negara Republik Indonesia Tahun 1945, pelestarian Bhinneka Tunggal Ika serta pemertahanan dan pemeliharaan keutuhan Negara Kesatuan Republik Indonesia;

b. Pembinaan persatuan dan kesatuan bangsa;

c. Pembinaan kerukunan antarsuku dan intrasuku, umat beragama, ras, dan golongan lainnya guna mewujudkan stabilitas kemanan lokal, regional, dan nasional;

d. Penanganan konflik sosial sesuai ketentuan peraturan perundang-undangan. e. Koordinasi pelaksanaan tugas antarinstansi pemerintahan yang ada di wilayah Daerah provinsi dan Daerah kabupaten/kota untuk menyelesaikan permasalahan yang timbul dengan memperhatikan prinsip demokrasi, hak asasi manusia, pemerataan, keadilan, keistimewaan dan kekhususan, potensi serta keanekaragaman Daerah sesuai dengan ketentuan peraturan perundang-undangan;

f. Pengembangan kehidupan demokrasi berdasarkan Pancasila; dan

g. Pelaksanaan semua Urusan Pemerintahan yang bukan merupakan kewenangan Daerah dan tidak dilaksanakan oleh Instansi Vertikal.

Tugas dan wewenang gubernur tersebut tidak dapat berjalan dengan baik pada dalam era titik berat otonomi pada Daerah Kabupaten/Kota, karena masih adanya anggapan bahwa hanya daerah kabupaten/kota yang otonom sedangkan Daerah Provinsi hanya satuan pemerintahan yang melaksanakan tugas dari Pemerintah Pusat saja. Daerah otonom, termasuk di dalamnya Kabupaten/Kota di samping berhak untuk mengatur dan mengurus sendiri urusan pemerintahannya, memilih pimpinan daerah, mengelola aparatur daerah, mengelola kekayaan daerah, memungut pajak daerah dan retribusi daerah, mendapatkan bagi hasil dari pengelolaan sumber daya alam dan sumber daya lainnya yang berada di daerah, mendapatkan sumber-sumber pendapatan lain yang sah; dan mendapatkan hak lainnya yang diatur dalam Peraturan perundang-undangan. Tetapi juga berkewajiban untuk:

a. Melindungi masyarakat, menjaga persatuan, kesatuan dan kerukunan nasional serta keutuhan Negara Kesatuan Republik Indonesia;

b. Meningkatkan kualitas kehidupan, masyarakat;

c. Mengembangkan kehidupan demokrasi;

d. Mewujudkan keadilan dan pemerataan; 
e. Meningkatkan pelayanan dasar pendidikan;

f. Menyediakan fasilitas pelayanan kesehatan;

g. Menyediakan fasilitas sosial dan fasilitas umum yang layak;

h. Mengembangkan sistem jaminan sosial;

i. Menyusun perencanaan dan tata ruang daerah;

j. Mengembangkan sumber daya produktif di daerah;

k. Melestarikan lingkungan hidup;

1. Mengelola administrasi kependudukan;

m. Melestarikan nilai sosial budaya;

n. Membentuk dan menerapkan peraturan perundang-undangan sesuai dengan kewenangannya; dan

o. Kewajiban lain yang diatur dalam peraturan perundang-undangan.

Ada kekhawatiran kelihatannya, jika titik

berat otonomi diletakan pada provinsi, terutama berkaitan dengan kedudukan gubernur sebagai Kepala Daerah Otonom yang memiliki wewenang untuk mengatur dan mengurus urusan rumah tangga daerah dengan prinsip otonomi seluas-luasnya. Kedudukan dan Penguatan peran gubernur sebagai kepala daerah dapat memperkuat orientasi pengembangan wilayah dan memperkecil dampak kebijakan desentralisasi terhadap fragmentasi spasial, sosial, dan ekonomi di daerah. Kedudukan demikian sebagian pihak mengkhawatirkan bentuk negara kesatuan mengarah ke federasi apabila gubernur memiliki kewenangan sepenuhnya sebagai kepala daerah. Padahal, peran gubernur sangat penting sebagai unsur perekat Negara Kesatuan Republik Indonesia (NKRI) yang bertanggungjawab kepada presiden dalam kedudukannya sebagai wakil pemerintah pusat. (Ikhwal Syamsul Situmeang, http://politik.kompasiana.com/ 2011/09/22/reposisi-peran-gubernur-dalam-uupemerintahan-daerah-381878.html, diunduh pada tanggal 10 Januari 2016).

Konsekuensi sistem pemerintahan lokal berkarakter integrated prefectoral system yang diterapkan di Indonesia adalah hirarki daerah otonom serta gubernur mempunyai kewenangan untuk mengoordinasi, mengawasi, menyupervisi, dan memfasilitasi agar daerah mengoptimalkan penyelenggaraan otonominya. Gubernur juga mempunyai kekuasaan pengawasan (tutelage power), yaitu kewenangan membatalkan kebijakan daerah yang bertentangan dengan kepentingan umum atau peraturan perundang-undangan yang lebih tinggi.

Memperhatikan hal tersebut di atas, kebijakan titik berat otonomi pada Daerah Provinsi sebenarnya tinggal ada atau tidak kemauan politik penguasa, memang ada kekhawatiran, ketika titik berat otonomi yang seluas-luasnya diletakan pada Daerah Provinsi, maka Daerah Provinsi akan memiliki posisi tawar yang sangat besar di hadapan Pemerintah Pusat, terlebih lagi apabila 34 (tiga puluh empat) Daerah Provinsi bersatu untuk menentang sebuah kebijakan yang dikeluarkan oleh Pemerintah Pusat, maka ancaman disintegrasi bangsa sangat terbuka. Namun demikian sebagaimana telah dikemukakan di atas, bahwa pemikiran tersebut sebenarnya tidak perlu terjadi jika ada pemahaman yang benar mengenai pilihan bentuk negara kesatuan, karena berbicara bentuk negara kesatuan, maka hakekatnya semua urusan pemerintahan sebenarnya sebenarnya milik Pemerintah Pusat, sedangkan satuan pemerintahan daerah otonom tidak lebih dari "pelaksana" kebijakan

Pemerintah Pusat, sehingga tidak ada alasan ketika daerah "dilibatkan" mengatur dan mengurus urusan pemerintahan melalui mekanisme desentralisasi, merasa sebagai "pemilik" urusan pemerintahan tersebut.

Memperhatikan hal tersebut di atas, maka ada "kecurigaan" bahwa pelaksanaan kebijakan titik berat otonomi pada Daerah Kabupaten/ Kota lebih bersifat politis, karena Daerah 
Kabupaten dan Daerah Kota kurang tidak mempunyai posisi tawar (bargaining position) di hadapan Pemerintah Pusat, di samping itu secara ekonomis posisi Daerah Kabupaten/Kota juga rendah jika dilihat dari kemampuan keuangan daerahnya, karena hampir semua Daerah Kabupaten/Kota sangat mengandalkan supporting dana dari Pemerintah Pusat untuk dapat membiayai pelaksanaan pemerintahan daerahnya. Oleh karena itu, maraknya pemekaran daerah otonomi baru, khususnya Daerah Kabupaten/Kota lebih didasarkan atas pertimbangan-pertimbangan untuk "mendapatkan kue kekuasaan" dengan harapan akan turunnya dana dari Pemerintah Pusat. Di samping itu, tingkat fanatisme kedaerahan pada Daerah Kabupaten/Kota juga relative kecil, sehingga resiko separatisme dan peluang berkembangnya aspirasi masyarakat federasi secara relatif sangat kecil.

Berdasarkan hasil evaluasi yang dilakukan oleh Kemendagri menunjukan bahwa bahwa sebagian besar Daerah Otonomi Hasil Pemekaran (DOHP) belum berhasil mewujudkan kinerja yang tinggi sehingga pembentukan DOHP tidak otomatis membuat daerah langsung menjadi lebih baik dari sebelum dimekarkan. DOHP pada masa awal terbentuknya tampaknya masih disibukkan melakukan penataan infrastaruktur pemerintahan dan personil, yang mempengaruhi kemampuan mereka untuk menjalankan fungsi-fungsi pemerintahan dan pelayanan publik. (Laporan Hasil Evaluasi Daerah Otonom Hasil Pemekaran (EDOHP), 2011: 40). Bahkan dalam suatu kesempatan Menteri Dalam Negeri Gamawan Fauzi menilai, pemekaran wilayah yang sudah dilakukan hingga kini belum memberikan hasil yang memuaskan bagi kesejahteraan rakyat. Gamawan bahkan mengatakan dari hasil evaluasi yang dilakukan pemerintah 70 persen dari 205 daerah otonom baru (DOB) gagal.
(Gamawan Fauzi, http://nasional.kompas.com/ $\mathrm{read} / 2012 / 12 / 15 / 06072741 /$

Mendagri.70.Persen.Pemekaran.Daerah.Gagal).

Sebagaimana telah dikemukakan di atas, bahwa pilihan kebijakan titik berat otonomi seluas-luasnya pada Daerah Provinsi akan membuat posisi tawar Daerah Provinsi yang tinggi dihadapan Pemerintah Pusat, tetapi juga akan mempermudah koordinasi dan evaluasi dan pembinaan yang dilakukan oleh provinsi terhadap satuan pemerintahan yang lebih rendah, baik kepada Daerah Kabupaten maupun Kota. Dengan demikian peran Gubernur sebagai Kepala Daerah Otonom sekaligus sebagai Wakil Pemerintah Pusat akan lebih efektif.

Pada negara-negara yang memiliki kebija-kan desentralisasi dua lapis (daerah provinsi dan kabupaten/kota), terdapat berbagai argumen yang mendasari lahirnya kebijakan seperti ini. Kondisi masyarakat yang berada lebih dekat dengan pemerintah kabupaten/kota dibandingkan provinsi, perlunya efisiensi dan efektivitas birokrasi pemerintahan daerah, serta kemudahan bagi pemerintah daerah untuk melihat persoalan yang ada di tengah-tengah masyarakat, merupakan beberapa argumen yang mendasari kebijakan titik berat berada pada daerah kabupaten/kota. Kebijakan desentralisasi dua lapis ini juga menghadirkan perdebatan yang hangat terkait dengan pemberian titik berat otonomi daerah, antara di provinsi dengan di kabupaten/kota. (Djohermansyah, Djohan, http://www.harianhaluan.com/ index.php?option $=$ com _content\&view $=$ article $\&$ id $=7628$ :titik-beratotonomi-daerah\& catid=12:refleksi\& Itemid =82, diunduh pada tanggal 10 Januari 2016).

Untuk mempermudah pelaksanaan kebijakan titik berat otonomi pada Daerah Provinsi, maka diusulkan agar desentralisasi yang dilaksanakan pada sistem ketatanegaraan RI yang akan datang adalah desentralisasi satu 
lapis, bukan desentralisasi dua lapis yang terdiri dari Daerah Provinsi dan Daerah Kabupaten/ Kota melainkan desentralisasi satu lapis atau satu tingkat, maka Daerah Provinsi merupakan satu-satunya daerah otonom, sedangkan eksistensi Kabupaten/Kota hanyalah merupakan wilayah adminisratif saja.

Perlunya desentralisasi satu tingkat/lapis dalam penyelenggaraan pemerintahan daerah dengan kebijakan titik berat otonomi pada Daerah Provinsi paling tidak ada 2 (dua) alasan, pertama, untuk mewujudkan effisiensi struktural pemerintahan dan kedua mewujudkan demokrasi lokal yang sebenarnya. Apabila otonomi daerah hanya satu tingkat effisiensi struktural akan terwujud, koordinasi menjadi efektif karena pemerintah pusat cukup mengoordinasikan dan berkoordinasi dengan gubernur saja dan gubernur cukup mengoordinasikan dan berkoordinasikan dengan Bupati dan Walikota di wilayahnya. Tidak seperti sekarang garis koordinasi menjadi tidak jelas dan tidak efektif, Bupati dan Walikota merasa tidak cukup berkoordiansi dengan Gubernur sehingga berkeliaran di Jakarta untuk berkoordinasi dengan pemerintah pusat. Bahkan banyak Bupati dan Walikota yang "melambung" melompati Gubernur dan merasa tidak ada gunanya berkoordinasi dengan Gubernur. Di mana-mana di dunia ini sistem pemerintahan ada jenjang dan hirarki. Sehingga tidak heran Bupati dan Walikota lebih sering berada di Jakarta di banding di Daerahnya sendiri. Di lain pihak Gubernur seperti tidak punya cukup kewenangan dan tidak punya daya untuk mengatur Bupati dan Walikota di wilayahnya. Posisi Gubernur menjadi ambigu apakah dia wakil pemerintah pusat atau wakil daerahnya mungkinkah efektif pada satu peran melekat dua kepentingan. (http:// birokrasi.kompasiana.com/2011/06/16/ otonomi-daerah-cukup-satu-tingkat-masukanuntuk-revisi-undang-undang-otda-373338.html, diunduh pada tanggal 10 Januari 2016).

Memperhatikan hal tersebut, maka anggapan bahwa menempatkan titik berat penyelenggaraan otonomi daerah di tingkat provinsi, dapat menyebabkan penyelenggaraan pelayanan publik menjadi kurang cepat, karena pengambil kebijakan di provinsi memiliki rentang kendali yang relatif jauh dari masyarakat, tidaklah tepat, karena dengan kewenangan yang dimiliki, Gubernur sebagai Kepala Daerah sekaligus Wakil Pemerintah Pusat mempunyai kewenangan untuk mendelegasikan kepada Bupati atau Walikota. Di beberapa negara praktek kebijakan titik berat otonomi pada Daerah Provinsi telah dilakukan, antara lain China, Spanyol dan Jepang, dengan kebijakan titik berat otonomi pada Daerah Provinsi telah membawa negara-negara tersebut berhasil menciptakan jalannya koordinasi dengan baik dan harmonis antar satuan Pemerintah Pusat dengan Pemerintah Daerah, dan antara Pemerintah Daerah Provinsi dengan Kabupaten/Kota sehingga efektifitas dan stabilitas penyelenggaraan pemerintahan dapat berjalan sebagaimana mestinya. (Resa Indrawan Samir, http://

resaindrawansamir.wordpress.com/2011/05/ 26/pengembalian-titik-berat-otonomi-ditingkatprovinsi/, diunduh pada tanggal 10 Januari 2016).

Rentang kendali penyelenggaraan pemerintahan yang relatif jauh dari tingkat provinsi hingga ke tengah-tengah masyarakat, merupakan salah satu persoalan besar yang menyulitkan implementasi titik berat otonomi daerah di tingkat provinsi. Namun demikian hal tersebut bisa di atasi manakala kedudukan Kabupaten/Kota bukan sebagai Daerah Otonom, melainkan sebagai Wilayah Administratif, sehingga Bupati/Walikota merupakan perangkat Daerah Provinsi, dan oleh karenanya merupakan kepanjangan tangan Gubernur. Menempatkan kedudukan Bupati/Walikota 
sebagai perangkat Pemerintah Daerah Provinsi akan merubah mekanisme pengisian jabatan Bupati/Walikota yakni melalui pengangkatan oleh Gubernur melalui sistem karier yang akan menjamin terbebasnya birokrasi pemerintahan dan Pegawai Negeri Sipil (PNS) terkooptasi oleh kepentingan-kepentingan politik praktis dan pragmatis, (Muhammad Fauzan Dkk, 2013: 134) dan ini akan menghemat keuangan negara/ keuangan daerah yang sangat besar.

Perubahan kedudukan Kabupaten/Kota dari Daerah Otonom menjadi Wilayah Administratif atau dapat disebut juga sebagai Kabupaten/Kota Administratif berakibat eksistensi DPRD Kabupaten/Kota menjadi tidak ada, dengan demikian akan terjadi penghematan terhadap keuangan negara, tetapi juga bisa berimbas banyaknya orang yang kehilangan "kesibukan". Sebagaimana diketahui, bahwa jumlah Kabupaten/Kota di Indonesia sebanyak 539, jika dirata-rata setiap pemilihan Kepala Daerah (Bupati/Walikota) menghabiskan dana yang bersumber dari Anggaran Pendapatan dan Belanja Daerah (APBD) sebesar 17 (tujuh belas) miliar, (http://regional.kompas.com/read/ 2012/09/03/10011128/

Pilkada.Serentak.untuk.Efisiensi.Anggaran, diunduh pada tanggal 10 Januari 2016). maka akan terdapat penghematan keuangan daerah sebesar Rp. 9.163.000.000.000,- (sembilan triliun seratus enam puluh tiga miliar rupiah), dana itu belum termasuk dana yang dikeluarkan oleh kandidat/calon Bupati/Wakil Bupati, sebagai gambaran seorang yang terpilih menjadi Bupati/ Walikota jika dirata-rata menghabiskan dana sekitar Rp. 4.000.000.000,-(empat miliar rupiah), (Wawancara dengan salah seorang Bupati terpilih di wilayah eks. Karesidenan Banyumas.) Dengan demikian maka dana yang dibutuhkan untuk menghasilkan Bupati/Walikota di seluruh Kabupaten/Kota yang ada di Indonesia sebesar Rp. 2.156.000.000.000,- (dua triliun seratus lima puluh enam miliar rupiah).
Sebagai ilustrasi, Penentuan besarnya uang representasi/gaji pimpinan dan anggota DPRD Kabupaten/Kota disusun berdasarkan PP No. 21 Tahun 2007 tentang Perubahan ketiga PP No. 24 Tahun 2004 tentang Kedudukan Protokoler dan Keuangan Pimpinan dan Anggota DPRD, data diperoleh dari Lampiran Perda APBD di beberapa Kabupaten eks. Karesidenan Banyumas. jika setiap Kabupaten/ Kota memiliki DPRD dengan jumlah anggota rata-rata rata-rata 45 (empat puluh lima) orang, maka dana yang diperukan untuk membayar gaji pimpinan dan anggota serta biaya operasional DPRD sebesar Rp. 24.000.000.000,(dua puluh empat miliar rupiah) setiap tahun, maka akan terjadi penghematan keuangan negara/keauangan daerah sebesar Rp.

12.936.000.000.000,- (dua belas triliun sembilan ratus tiga puluh enam miliar rupiah). Namun di pihak lain akan berimbas hilangnya "kesibukan" dari sekitar 24.255 orang yang sebelumnya menjadi anggota DPRD.

Perubahan mekanisme pemilihan kepala daerah secara serentak berdasarkan Undangundang No. 22 Tahun 2014 jo Peraturan Pemerintah Pengganti Undang Undang (Perppu) No. 1 Tahun 2014 jo Undang-undang No. 1 Tahun 2015 tentang Penetapan Peraturan Pemerintah Pengganti Undang-Undang Nomor 1 Tahun 2014 Tentang Pemilihan Gubernur, Bupati, Dan Walikota Menjadi UndangUndang, mempunyai implikasi bahwa kebutuhan dana untuk penyelenggaraan pesta demokrasi tersebut semakin meningkat, hal tersebut karena berdasarkan Pasal 2 ayat (1) dan (2) Peraturan Menteri Dalam Negeri (Permendagri) No. 44 Tahun 2015 jo Permendagri Mo. 51 Tahun 2015 tentang Tentang Pengelolaan Dana Kegiatan Pemilihan Gubernur Dan Wakil Gubernur, Bupati Dan Wakil Bupati, Serta Walikota Dan Wakil Walikota dinyatakan bahwa Pendanaan kegiatan Pemilihan Gubernur dan Wakil Gubernur 
dibebankan pada APBD provinsi dan Pendanaan kegiatan Pemilihan Bupati dan Wakil Bupati/Walikota dan Wakil Walikota dibebankan pada APBD kabupaten/kota.

Berdasarkan uraian tersebut di atas, maka dapat disimpulkan bahwa jika kebijakan titik berat otonomi pada Daerah Provinsi dilaksanakan, Pertama, kedudukan Kabupaten/ Kota berubah statusnya dari Daerah Otonom menjadi Kabupaten/Kota Administratif, sebagai konsekusnsi perubahan status, maka pengisian jabatan Bupati/Walikota diangkat dari Pegawai Negeri Sipil (PNS) yang memenuhi persyaratan, konsekuensi pengisian jabatan Bupati/Walikota yang demikian tentunya harus terlebih dahulu dilakukan amandemen terhadap UUD 1945, khususnya Pasal 18 ayat (4), karena pasal tersebut menganatkan bahwa: Gubernur, Bupati, dan Walikota masing-masing sebagai kepala pemerintah daerah provinsi, kabupaten, dan kota dipilih secara demokratis.. Kedua, hanya pengisian jabatan Kepala Daerah Provinsi yang dilakukan melalui pemilihan umum secara langsung. Ketiga, eksistensi DPRD Kabupaten/Kota ditiadakan.

\section{PENUTUP}

\section{A. SIMPULAN}

Berdasarkan uraian dan pembahasan tersebut di atas, maka dapat disimpulkan bahwa dalam perspektif normatif peluang titik berat otonomi pada daerah provinsi pada masa yang akan datang sangat terbuka, hal tersebut dikarenakan Pasal 18 UUD 1945 hasil amandemen menganut kebijakan terbuka (open legal policy) mengenai otonomi daerah dan titik berat otonomi daerah. Dalam ketentuanketentuan tersebut, tidak mengatur di mana titik berat otonomi daerah diletakan. Dengan demikian kebiajakan titik berat otonomi daerah sangat tergantung pada kemauan politik pembuat undang-undang dengan memperhatikan situasi negara, seperti politik, keamanan, ekonomi dan kemasyarakatan saat undang-undang dibuat, dan kebijakan titik berat otonomi daerah pada Daerah Provinsi maupun pada Daerah Kabupaten/Kota tidak bertentang dengan UUD RI Tahun 1945.

\section{B. SARAN}

Dengan memperhatikan keberagaman daerah baik usul maupun kondisi daerah yang sangat heterogen, maka perlu dicoba diberlakukan kebijakan yang berbeda antara daerah otonom, bagi Daerah Kabupaten/ Kota yang telah memiliki kemampuan baik sumber daya manusia maupun sumber dana, maka kebijakan titik berat otonomi pada Daerah Kabupaten/ Kota untuk tetap dilanjutkan, namun demikian bagi Daerah Kabupaten/Kota yang belum memiliki kemampuan, maka pilihan kebijakan titik berat otonomi pada Daerah Provinsi menjadi alternatif pilihan pada masa yang akan datang, dengan demikian berkaitan dengan kebijakan titik berat otonomi model one state multy system dapat dilaksanakan dalam penyelenggaraan pemerintahan daerah salam sistem ketatanegaraan RI pada masa yang akan datang.

\section{DAFTAR PUSTAKA:}

Buku Teks:

Anonimous, Laporan Hasil Evaluasi Daerah Otonom Hasil Pemekaran (EDOHP) Tahun 2011, Direktorat Jenderal Otonomi Daerah Kementerian Dalam Negeri Didikung Oleh Decentralization Support Facility, Jakarta, 2011;

Chambers, Robert, 1987, Pembangunan Desa: Mulai Dari Belakang (Diterjemahkan oleh Pepep Sudradjat dari: Rural Development Putting the Last First), LP3ES, Jakarta.

Fauzan, Muhammad. 2005, Hubungan Keuangan antara Pusat Dan Daerah Dalam Tata Penyelenggaraan Pemerintahan di Indonesia, Disertasi UNPAD Bandung; , 2010, Hukum Pemerintahan Daerah (Kajian Tentang Hubungan Keuangan Antara Pemerintah Pusat Dan Daerah), Stain Press, Edisi Revisi, Purwokerto; -Dkk, 2013, PEMILUKADA (Rekontruksi Demokrasi Lokal Dalam Sistem Ketatanegaraan RI), Kanwa Publisher, Yogyakarta;

Manan, Bagir, 1993, Perjalanan Historis Pasal 18 UUD 1945 (Perumusan dan Undang-Undang Pelaksanaannya), UNSIKA, Karawang;

2001, Menyongsong Fajar Otonomi Daerah, PSH Fakultas Hukum UII, Yogyakarta; , 2013, Politik Hukum Untuk Otonomi 
Daerah, Varia Peradilan No. 337 Desember, Jakarta;

Rodee, Calton Clymer Dkk, Pengantar Ilmu Politik, Rajawali Pers, Jakarta, 1993;

Strong, C.F, Modern Political Constitution, The English Language Book Society and Sidgwick and Jackson Limited, London, 1966.

Utrecht, E, Pengantar Dalam Hukum Indonesia, Ichtiar, Jakarta, 1966.

Artikel

http://sp.beritasatu.com/home/peletakan-otonomi-daerah-padaprovinsi-tidak-langgar-konstitusi/88548

Resa Indrawan Samir, http://resaindrawansamir.wordpress.com/ 2011/05/26/ pengembalian-titik-berat-otonomi-ditingkatprovinsi/)

http://edikuncoro.wordpress.com/2010/10/27/otonomi-daerahsebelum-amandemen-uud-1945/

http://politik.kompasiana.com/2011/09/22/reposisi-perangubernur-dalam-uu-pemerintahan-daerah-381878.html

http://nasional.kompas.com/read/2012/12/15/06072741/ Mendagri.70.Persen.Pemekaran.Daerah.Gagal

Djohermansyah Djohan, http://www.harianhaluan.com/ index.php?option $=$ com_content \&view $=$ article\&id $=7628$ : titik-berat-otonomidaerah\&catid=12:refleksi \&ltemid=82http:// www.harianhaluan.com/ index. php?option $=$ com content $\&$ view $=$ article $\&$ id $=7628$ : titikberat-otonomi-daerah\&catid $=12$ : refleksi\&ltemid $=82$

http://birokrasi.kompasiana.com/2011/06/16/otonomi-daerahcukup-satu-tingkat-masukan-untuk-revisi-undang-undangotda-73338.

htmlhttp://resaindrawansamir.wordpress.com/2011/05/26/ pengembalian-titik-berat-otonomi-ditingkat-provinsi/)

http://regional.kompas.com/read/2012/09/03/10011128/ Pilkada.Serentak.untuk.Efisiensi.Anggaran

Peraturan Perundang-undangan:

UUD 1945 Sebelum Amandemen

UUD 1945 Setelah Amandemen

Undang-undang No. 18 Tahun 1965 tentang Pemerintahan Daerah

Undang-undang No. 5 Tahun 1974 tentang Pokok Pokok Pemerintahan di Daerah

Undang-undang No. 22 Tahun 1999 Tentang Pemerintahan Daerah

Undang-undang No. 32 Tahun 2004 tentang Pemerintahan Daerah

Undang-undang No. 22 Tahun 2014 tentang Pemilihan Gubernur, Bupati dan Walikota

Undang-undang No. 23 Tahun 2014 tentang Pemerintahan Daerah Peraturan Pemerintah No. 45 Tahun 1992 tentang Tentang Penyelenggaraan Otonomi Daerah Dengan Titik Berat Pada Daerah Tingkat II

Peraturan Menetri Dalam Negeri No. 44 Tahun 2015 tentang Pengelolaan Dana Kegiatan Pemilihan Gubernur Dan Wakil Gubernur, Bupati Dan Wakil Bupati, Serta Walikota Dan Wakil Walikota

Peraturan Pemerintah No. 51 Tahun 2013 tentang Perubahan Atas Peraturan Menteri Dalam Negeri Nomor 44 Tahun 2015 Tentang Pengelolaan Dana Kegiatan Pemilihan Gubernur Dan Wakil Gubernur, Bupati Dan Wakil Bupati,Serta Walikota Dan Wakil Walikota. 